\title{
"Königsberger Hartungsche Zeitung” jako źródło do dziejów wschodniopruskiego szkolnictwa średniego w II połowie XIX w.
}

\begin{abstract}
O przydatności prasy w badaniach naukowych przekonani byli już historycy tworzący w XIX w. ${ }^{1}$, a pełna jej rehabilitacja jako źródła historycznego nastąpiła po drugiej wojnie światowej ${ }^{2}$. Wartość prasy doceniono również na gruncie historii edukacji, co przejawia się w postaci monografii, w których jako główny materiał źródłowy wykorzystano czasopiśmiennictwo, a także w publikacjach zawierających zalecenia metodologiczne na temat wykorzystania prasy w badaniach historyczno-oświatowych. O wartości prasy w tym zakresie przekonani są Iwonna i Grzegorz Michalscy:
\end{abstract}

Z historyczno-pedagogicznego punktu widzenia rola czasopism polega na tym, że odnotowują zjawiska i wydarzenia, które często z powodu swej ulotności nie są zapisane w innych źródłach. Pozwalają więc następnym pokoleniom krok po kroku zgłębiać i wzbogacać wiedzę o dziejach szkolnictwa, oświaty i edukacji. Pomagają w niemałym stopniu i zakresie wyjaśniać problemy nierozwiązane dotychczas w historiografii oświatowo-pedagogicznej³.

Alicja Kicowska pisze w następujący sposób o znaczeniu prasy w badaniach nad dziejami wychowania:

* Dr, Ośrodek Badań Naukowych im. W. Kętrzyńskiego, ul. Partyzantów 87, 10--402 Olsztyn.

${ }^{1}$ B. K r z y w o b ł o c k a, Prasa jako źródło historyczne, [w:] Metody i techniki badawcze w prasoznawstwie, red. M. Kafel, t. 3, Warszawa 1971, s. 60-61.

${ }^{2}$ I. i G. M i ch a I s c y, Wstęp, [w:] Czasopiśmiennictwo XIX i początków XX wieku jako źródło do historii edukacji, red. I. i G. M i c h a I s c y, Łódź 2010, s. 5; I. M i c h a I s k a, Wybrane problemy metodologiczne wykorzystania prasy jako źródła w badaniach historii wychowania, [w:] Źródła w badaniach naukowych historii edukacji, red. W. Szulakiewicz, Toruń 2003, s. 128-129; A. K i c o w s k a, Prasa jako źródło w badaniach historii wychowania, [w:] Metodologia w badaniach naukowych historii wychowania, red. I. i G. Michalscy, T. Jałmużna, Łódź 1993, s. 235.

${ }^{3}$ I. i G. M i ch a I s c y, Wstęp..., s. 5. 
Wykorzystanie źródeł prasowych umożliwia także analizowanie problemów wychowania w kontekście upowszechnionych poglądów politycznych, społecznych, ekonomicznych, kulturalnych, wreszcie na tle problemów życia codziennego społeczeństwa. Jest więc [prasa - przyp. T.Ch.] źródłem zawierającym informacje bezpośrednio i pośrednio związane z przedmiotem badań historii wychowania. Prasę można też wykorzystać jako źródło zastępcze w przypadku, gdy zachowana baza źródłowa badanego problemu jest nader skromna i niewystarczająca ${ }^{4}$.

Celem niniejszego artykułu jest próba scharakteryzowania regionalnej prasy codziennej jako źródła do dziejów męskiego szkolnictwa średniego w Prusach Wschodnich w XIX w. Poprzez analizę zawartości wybranych roczników gazety „Königsberger Hartungsche Zeitung” z drugiej połowy XIX w. (cezury wyznaczają kres Wiosny Ludów i nadanie czasopismu nowego tytułu oraz wybuch pierwszej wojny światowej) pragniemy odpowiedzieć na pytanie, czy dla historyka edukacji są przydatne doniesienia prasowe dotyczące wschodniopruskich szkół średnich?

„Königsberger Hartungsche Zeitung” była typowym dziennikiem informacyjnym, poświęconym w znacznej mierze doniesieniom politycznym z kraju i ze świata, ale i odnotowującym wiele wydarzeń z prowincji (wschodnio)pruskiej. Analizując prasę codzienną, należy zastanowić się nad jej miejscem w hierarchii ważności źródeł historycznych, ustalanej dla historyczno-oświatowego problemu badawczego. Na tę kwestię zwróciła uwagę I. Michalska, nie odbierając rangi prasie codziennej w badaniach historyczno-oświatowych:

Wykorzystanie dzienników jako źródła informacji o przeszłości oświatowej nie ma wprawdzie zasadniczego znaczenia, ale posiada ten walor, iż na łamach gazet można niejednokrotnie odnaleźć, cenny z punktu widzenia badawczego, materiał dotyczący zdarzeń o charakterze typowo ulotnym. Pismo codzienne, śledząc na bieżąco życie społeczne, rejestruje większość z nich5.

W naszym przekonaniu, o prasie codziennej w badaniu dziejów męskiego szkolnictwa średniego w Prusach Wschodnich w XIX w. z pewnością nie można mówić jako o źródle podstawowym, pierwszorzędnym, ale raczej zastępczym i uzupełniającym. Przydatność i wiarygodność informacji odnajdywanych w prasie codziennej i niepedagogicznej musi być weryfikowana poprzez konfrontację z podaniami wielu innych materiałów źródłowych. Historyk dziewiętnastowiecznej edukacji w Prusach Wschodnich jako podstawowe źródło do dziejów męskiego szkolnictwa średniego musi, wobec niedostatecznego stopnia zachowania materiałów archiwalnych, traktować - będące w istocie również wydawnictwami ciągły$\mathrm{mi}$ - coroczne sprawozdania szkół średnich, do których wydawania zobligowana była od 1824 r. każda publiczna szkoła średnia. W tych programach szkolnych informowano m.in. o realizowanym programie nauczania, składzie kolegium nauczycielskiego, liczbie zatrudnionych nauczycieli. Sprawozdania szkolne miały przez dziesięciolecia dychotomiczną strukturę: obejmowały rozprawę naukową reprezentanta grona nauczycielskiego danej szkoły oraz zawierały szereg danych

\footnotetext{
${ }^{4}$ A. Ki cow s k a, Prasa..., s. 236.

5 I. M i ch a I s k a, Wybrane problemy..., s. 143.
} 
statystycznych i innego typu informacji, dotyczących minionego roku szkolnego. Nie oznacza to jednak, że te szkolne publikacje, ograniczane swym „urzędowym” charakterem, w pożądany sposób naświetlają wszelkie aspekty działalności szkoły. Poszukując pełniejszego obrazu rozwoju szkolnictwa średniego, historyk edukacji powinien sięgać do innych źródeł ${ }^{\dagger}$. Odnośnie do czasopism warto wspomnieć, że w dziewiętnastowiecznych Prusach ukazywało się wiele tytułów uznawanych za fachową prasę pedagogiczną, przede wszystkim zaś wydawany z inicjatywy ministerstwa oświaty periodyk „Centralblatt für die gesammte Unterrichts-Verwaltung in Preußen” (zawierający m.in. dane statystyczne wszystkich szczebli kształcenia oraz najnowsze rozporządzenia ministerialne). Ponadto warto wspomnieć, że swe własne organa prasowe miały rozwijające się bujnie zwłaszcza w drugiej połowie XIX stulecia - towarzystwa nauczycielskie.

W niniejszym artykule skupiamy się na analizie informacji dotyczących męskiego szkolnictwa średniego, mającego zupełnie inne tradycje i linie rozwoju w interesującym nas stuleciu od szkolnictwa żeńskiego, prawnie w pełni usankcjonowanego dopiero na początku XX w. Wprowadzone w państwie pruskim na początku XIX w. reformy, kojarzone z nazwiskiem Wilhelma von Humboldta, ustaliły jako główny typ szkół średnich gimnazja humanistyczne, obok których w ciągu stulecia coraz silniej swe wpływy zaznaczał nurt realny (w postaci szkół realnych, wyższych szkół obywatelskich, pro- i gimnazjów realnych oraz wyższych szkół realnych), kładący większy nacisk na kształcenie w zakresie przedmiotów ścisłych. Męskie szkolnictwo średnie dysponowało własnymi regulacjami prawnymi i programami nauczania. Również nauczyciele szkół średnich musieli spełniać szczególne wymagania, przede wszystkim w większości przypadków musieli się legitymować wyższym wykształceniem i zdanym egzaminem na nauczyciela szkoły średniej (pro facultate docendi) ${ }^{7}$.

Początki „Königsberger Hartungsche Zeitung” są związane z nadaniem 9 lipca 1660 r. przez księcia pruskiego Fryderyka Wilhelma przywileju królewieckiemu drukarzowi Janowi Reußnerowi, na podstawie którego wydawca mógł rozpowszechniać informacje polityczne pochodzące $z$ dworu książęcego w swej gazecie „Europäischer Mercurius”, wychodzącej początkowo dwa razy w tygodniu. Nazwa tego czasopisma w późniejszym okresie ulegała wielokrotnie zmianom, zmieniali się również jego właściciele. W 1751 r. drukarnia

${ }^{6}$ T. C h r z a n o w s k i, „Jahresberichten” jako źródło do dziejów edukacji (na przykładzie sprawozdań wschodniopruskich szkół średnich z XIX wieku), „Klio. Czasopismo poświęcone dziejom Polski i powszechnym" 2011, nr 16, s. 77-93.

${ }^{7}$ Literatura niemiecka dotycząca rozwoju męskiego szkolnictwa średniego w XIX w. jest bardzo bogata. Zaznaczmy jedynie, że w ostatnim czasie o starciu nurtu realnego i humanistycznego w drugiej połowie stulecia pisze: T. V a n č a, Der Schulkrieg 1870-1901. Der Humanismus-Realismus-Streit im höheren Schulwesen Preußens am Ende des 19. Jahrhunderts - Eine Einführung, Berlin 2006. Na gruncie polskim o szkolnictwie średnim w prowincjach pruskich w XIX w. m.in.: M. N i e d z i e I s ka, Szkolnictwo powszechne i średnie oraz oświata, [w:] Historia Pomorza, red. G. Labuda, t. 3: 18151850, cz. 3, Poznań 2001, s. 127-169; t a ż, Dzieje szkolnictwa, [w:] Historia Pomorza, red. S. S a I m o n o w i c z, t. 4: 1850-1918, cz. 2, Toruń 2002, s. 271-303. 
Reußnera wraz z tytułem gazety została wykupiona przez rodzinę Hartungów ${ }^{8}$, której cztery kolejne pokolenia kierowały losami gazety9.

W 1831 r. gazeta zaczęła ukazywać się codziennie. Zmiana charakteru pisma była możliwa po objęciu tronu królewskiego przez Fryderyka Wilhelma IV (1840) i wydaniu nowego rozporządzenia w sprawie cenzury z 24 grudnia 1841 r., po którym w gazecie w sposób bardziej prostolinijny poruszano poglądy polityczne. $Z$ powodu liberalnego stanowiska czasopisma Hartungów w okresie Wiosny Ludów, w maju 1850 r. odebrano gazecie dotychczasowy „królewski” tytuł „Königlich Preussische Staats-, Kriegs- und Friedenszeitung" oraz prawo wykorzystywania godła królewskiego. Od tego roku czasopismo wychodziło pod tytułem „Königsberger Hartungsche Zeitung” (KHZ) ${ }^{10}$. Około 1850 r. jego nakład wynosił 4175 egzemplarzy. W drugiej połowie stulecia gazeta, wciąż liberalna i postępowa pod względem ideowym, sprzyjała Niemieckiej Partii Postępowej i stała się jej organem prasowym. Od początku 1871 r. ukazywała się dwa razy dziennie. W tym samym roku przestała być własnością Hartungów, co nie oznaczało jednak zmiany jej nazwy. W okresie cesarskim $\mathrm{KHZ}$ zyskała poważnego konkurenta na rynku królewieckim w postaci organu prasowego Partii Narodowo-Liberalnej, od 1882 r. noszącego tytuł „Königsberger Allgemeine Zeitung”. KHZ nie wyszła zwycięsko z rywalizacji z nowym konkurentem i systematycznie traciła popularność. Organ konserwatystów na początku lat dziewięćdziesiątych miał ponad dwa razy większy nakład niż KHZ. Zamknięcie czasopisma nastąpiło w okresie hitlerowskim - przestało się ukazywać w końcu 1933 r. ${ }^{11}$

W drugiej połowie stulecia na łamach interesującej nas gazety zamieszczano regularnie przewodni artykuł lub felieton, dotyczący bieżących spraw politycznych, społecznych lub kulturalnych. Bardzo rzadko tematem tego tekstu było męskie szkolnictwo średnie, przypadki takie jednak się zdarzały. W KHZ, sprzyjającej ideom postępowym, prezentowano zamierzenia reformatorskie, również w zakresie oświaty. Artykuły publikowane pod koniec XIX w., powstające w okresie permanentnej ogólnoniemieckiej dyskusji na temat kształtu szkolnictwa średniego i zmieniającej się sytuacji społeczno-gospodarczej, charakteryzują się dużą liczbą uwag krytycznych wobec gimnazjów humanistycznych. Bardzo rzadko na łamach $\mathrm{KHZ}$ problemy szkolnictwa średniego rozpatrywano z perspektywy Prus Wschodnich, ale jako przykład artykułu odnoszącego się bezpośrednio do sytuacji w tej prowincji może posłużyć anonimowy tekst poświęcony ocenie położenia młodszych nauczycieli szkół średnich, opublikowany w jednym z nume-

${ }^{8}$ M. Szostak ow ska, Prasa codzienna Prus Wschodnich od XVII do połowy XX wieku. Przewodnik do dziejów wydawniczych, Toruń 2007, s. 12-13; t a ż, „Königsberger Hartungsche Zeitung” w latach 1660-1933. Zarys dziejów wydawniczych, „Komunikaty Mazursko-Warmińskie” 1992, nr 2, s. 110.

${ }^{9}$ M. S z os ta k ow ska, Prasa codzienna..., s. 17-18; K. F or st r e u te r, Georg Friedrich Hartung (1782-1849), [w:] Deutsche Presseverleger des 18. bis 20. Jahrhunderts, Hrsg. H.-D. Fischer, Pullach bei München 1975, s. 102.

${ }_{10}$ M. S z o s t a k o w s k a, „Königsberger Hartungsche Zeitung”..., s. 11-115.

${ }_{11}$ M. S z o s t a k o w s k a, Prasa codzienna..., s. 29-33, 46; t a ż, „Königsberger Hartungsche Zeitung", s. 115-117. 
rów w 1888 r. Autor, doskonale znający ówczesne realia pruskiej oświaty, skarżył się na brak jednolitej ustawy szkolnej, regulującej kwestie zatrudniania i ścieżki awansu nauczycieli szkół średnich, a także ich odpowiedniego wynagradzania. Krytykował istniejące rozwiązania, ponieważ polityka kadrowa, opierająca się w poszczególnych szkołach na zasadzie starszeństwa, uniemożliwiała młodym nauczycielom znalezienie pracy ${ }^{12}$. Autor podkreślał, że problem ten szczególnie dotkliwie dotyczy szkolnictwa wschodniopruskiego, gdzie tylko niewielki odsetek kandydatów na posady nauczycielskie uzyskiwał zatrudnienie w szkole średniej, a okres oczekiwania na zatrudnienie znacznie się wydłużał. Przewidywał ponadto pogorszenie się perspektyw zawodowych młodych nauczycieli, ponieważ kadra szkół średnich była odmłodzona i brakowało perspektyw na szybkie podjęcie pracy przez młodsze osoby. Autor dziwił się ponadto, że wciąż tak wielu absolwentów szkół wyższych wiązało swe nadzieje zawodowe ze szkolnictwem średnim, krytykował całą politykę władz zwierzchnich na polu szkolnictwa średniego, które główną zasadą swej działalności uczyniły zasadę oszczędzania, co przejawiało się chociażby w redukcji nauczycielskich etatów i rekompensowaniu zwiększenia świadczeń dla nauczycieli podwyżkami czesnego (kosztem rodziców uczniów) ${ }^{13}$.

Inne artykuły o tematyce pedagogicznej, choć odnosiły się do ogólnej sytuacji szkolnictwa średniego, jak można przypuszczać, były publikowane z nadzieją, że spotkają się z zainteresowaniem opinii publicznej w Prusach Wschodnich. Jako przykład tego typu publikacji służy tekst anonimowego autora Die Überbürdung ${ }^{14}$ der Schüler höherer Lehranstalten z maja 1883 r., będący omówieniem wydanego przez komisję parlamentarną ds. oświaty memoriału poświęconego sprawie tzw. przeciążenia uczniów w szkołach średnich ${ }^{15}$. W artykule przedstawiono najnowsze wnioski władz zwierzchnich na temat tego problemu, dotyczącego przede wszystkim gimnazjów. Artykuł w KHZ stanowi przejaw zainteresowania tym zagadnieniem w prowincji i może służyć do analizy kondycji całego humanistycznego nurtu w szkolnictwie średnim w okresie cesarskim ${ }^{16}$.

W innym artykule krytyka gimnazjalnego programu nauczania była wynikiem rozwoju nauki i specjalizacji jej poszczególnych gałęzi. W jednym z numerów z 1883 r. ukazał się tekst Hermanna Hellera, postulującego wprowadzenie nauki historii sztuki do gimnazjów. Autor oparł swój artykuł na jednej z publikacji

12 Problem bezrobocia wśród młodych nauczycieli miał w latach osiemdziesiątych XIX w. charakter ogólnoniemiecki. Kanclerz Otto von Bismarck określił ich mianem „Abiturientenproletariat” zob. T. V a n č a, Der Schulkrieg..., s. 63-64.

13 X, Die Lage der jüngeren Lehrer höherer Unterrichtsanstalten, „Königsberger Hartungsche Zeitung“ (dalej: KHZ) 1888, Nr 196, s. 3144; Nr 197, s. 3163.

14 Terminu Überbürdung w odniesieniu do męskich szkół średnich jako pierwszy użył w latach trzydziestych XIX w. Karl Ignatius Lorisner, krytykujący fatalny stan zdrowia młodzieży gimnazjalnej jako wynik wadliwego programu nauczania - zob. L. L o h b e c k, Das höhere Schulwesen in Preußen im 19. Jahrhundert, Marburg 2005, s. 38; Encyklopädisches Handbuch des gesamten Turnwesens und der verwandten Gebiete, Hrsg. C. Euler, Bd. III, Wien-Leipzig 1896, s. 368.

15 Denkschrift, betreffend die Frage der Überbürdung der Jugend an unsern höheren Schulen, opublikowany m.in. w: „Pädagogisches Archiv“ 1883, Bd. XXV, Nr 6, s. 401-423.

16 Die Überbürdung der Schüler höherer Lehranstalten, KHZ 1883, Nr 117, s. 1625-1626. 
niemieckiego archeologa i historyka sztuki, ale i pedagoga, Friedricha Schlie, gorącego zwolennika nauczania historii sztuki w gimnazjach. W artykule dominowała teza o nieefektywności obecnego programu nauczania, Heller w przeciwieństwie do Schlie nie żądał jednak wprowadzenia nowego przedmiotu, lecz domagał się nauczania historii sztuki w ramach dotychczasowego - historii. Nauczanie historii sztuki jako obcowanie z wrażeniami estetycznymi miało również, według autora, w pewnym stopniu zrekompensować nieskuteczną naukę religii w szkołach średnich ${ }^{17}$.

$\mathrm{Na}$ łamach KHZ pojawiało się oczywiście wiele doniesień z Królewca. Niekiedy dotyczyły one również spraw pedagogicznych. Na przykład w jednym z lutowych numerów gazety z 1852 r. opublikowano tabelę zawierającą dane statystyczne na temat szkolnictwa królewieckiego z jesieni 1851 r., w której obok liczby szkół poszczególnych typów podano informacje na temat liczby nauczycieli, uczniów i oddziałów klasowych. Dane te konfrontowano ze statystyką z poprzednich lat, określano tendencję przyrostu lub spadku liczby uczniów w szkołach ${ }^{18}$. W KHZ zamieszczano często artykuły recenzujące najnowsze książki. Wśród nich można odnaleźć m.in. omówienia podręczników (w jednym z numerów z 1855 r. zrecenzowano skrypt Karla Koppe pod względem merytorycznym i wydawniczym) ${ }^{19}$.

Jak wspomniano, główne artykuły niezmiernie rzadko poświęcano problematyce męskiego szkolnictwa średniego, a - jak widać z przytoczonych przykładów - nie zawsze odnosiły się one do terenu Prus Wschodnich. Historyk edukacji mnóstwo informacji na temat funkcjonowania szkół średnich na terenie tej prowincji odnajdzie natomiast w dziale „Provinzielles”, w którym informowano o najważniejszych wydarzeniach w poszczególnych miastach i wsiach Prus Wschodnich. Rubryka ta ukazywała się regularnie prawie w każdym numerze gazety. Obok doniesień o tematyce politycznej, społecznej, kulturalnej, o anomaliach pogodowych, pożarach i innych niecodziennych zdarzeniach, znaczna część informacji dotyczyła spraw oświatowych. To właśnie dzięki analizie zawartości tej rubryki historyk edukacji może uzyskać potwierdzenie informacji dotyczących szkolnej codzienności, znanych z innych źródeł, a także poznaje nowe fakty na temat szkolnictwa średniego w Prusach Wschodnich. W gazecie zamieszczano m.in. wzmianki o wydarzeniach ważnych dla rozwoju szkoły i reakcjach na nie lokalnej społeczności. Relacjonowanie w prasie na bieżąco wydarzeń cechuje bowiem pamiętnikarska specyfika relacji, o której pisała Bożena Krzywobłocka ${ }^{20}$. Dzięki tego typu informacjom poznajemy więc stosunek lokalnej społeczności do szkoły średniej, znaczenie istnienia placówki dla miasta i okolicy. W drugiej połowie stulecia istotne problemy przeżywało progimnazjum w Olsztynku, w którym w 1852 r. z rozkazu władz oświatowych zamknięto naj-

${ }^{17} \mathrm{H}$. Helle r, Die Kunstgeschichte auf dem Gymnasium. Ein Beitrag zur Reform des Geschichtsunterrichts, KHZ 1883, Nr 164, s. 2209-2210.

$18 \mathrm{KHZ}$ 1852, Nr 45, s. 206.

$19 \mathrm{KHZ}$ 1855, Nr 77, s. 380.

${ }^{20}$ B. Krzy w obło ck a, Prasa..., s. 63. 
wyższą klasę - sekundę ${ }^{21}$. W końcu lipca tego roku wydrukowano na łamach $\mathrm{KHZ}$ informację o ministerialnym reskrypcie, nakazującym likwidację sekundy, donoszono również o reakcji ludności miasta i okolicy na to postanowienie, którą była prośba o zmianę decyzji hamującej rozwój szkoły²2. Inna z relacji dotyczących skasowania sekundy w Olsztynku zawierała obawy o dalszy spadek liczby uczniów progimnazjum, a także niepokój o pogorszenie stosunków między nauczycielami szkoły wobec konieczności wyboru nowego dyrektora. Za pośrednictwem tej wiadomości z jesieni 1852 r. (kiedy władze już zlikwidowały sekundę, co spowodowało spadek liczby uczniów, i kiedy odszedł dotychczasowy dyrektor) wyrażano troskę o kondycję zakładu w przyszłości²3.

O kierunkach rozwoju wschodniopruskiego szkolnictwa średniego dowiedzieć się można z informacji o dążeniach lokalnej społeczności do zmiany patronatu, pod którym szkoła się znajdowała. Dominującą tendencją w drugiej połowie stulecia były starania poszczególnych placówek o uzyskanie „królewskiego” statusu. Analiza zawartości „Provinzielles” pozwala m.in. na ustalenie dokładnej daty petycji olsztyńskich radnych miejskich do ministra oświaty z prośbą o przejęcie gimnazjum spod zarządu miejskiego przez państwo ${ }^{24}$. Wiele wzmianek dotyczyło okoliczności powstania nowych szkół średnich. Z informacji prasowych wynika, że w wielu przypadkach czynnikiem inicjującym powstanie szkoły średniej były władze miejskie, np. w Gołdapi na początku 1894 r., kiedy zdecydowano o utworzeniu szkoły realnej ${ }^{25}$. Niektóre informacje dotyczyły wydarzeń wynikających ze specyfiki religijnej obszaru, na którym funkcjonowała szkoła średnia. W 1894 r. doszło do powstania konwiktu w Reszlu na katolickiej Warmii, którego pracami kierował jeden z nauczycieli gimnazjalnych ${ }^{26}$.

Niektóre z relacji dotyczyły udziału szkoły średniej w wydarzeniach ważnych dla życia lokalnej społeczności i kraju. Do tego typu inicjatyw należały uroczyste obchody urodzin królewskich, organizowane corocznie w całej prowincji. W imprezach uczestniczyły, obok władz samorządowych, reprezentantów wojska i wschodniopruskich stowarzyszeń, również szkoły średnie. Na przykład w 1852 r. gimnazjum tylżyckie i wyższa szkoła obywatelska (późniejsze gimnazjum realne) odpowiadały za przygotowanie uroczystych mów i śpiewów ${ }^{27}$. Szkoły średnie współpracowały także z lokalnymi organizacjami kulturalnymi i społecznymi, również tymi, których profil ideowy nie odpowiadał w pełni założeniom niektórych środowisk politycznych. W Wystruci funkcjonowało Towarzystwo Schillera (Schillerverein), powstałe z okazji setnej rocznicy urodzin poety, któremu niechętne pozostawały czynniki konserwatywne, a sama postać Schillera

${ }^{21}$ G. S a c h s e, Geschichte der höheren Lehr-Anstalt in Hohenstein in Ostpreussen während ihres fünfzigjährigen Bestehens, Osterode Ostpr. 1895, s. 11.

22 KHZ 1852, Nr 179, s. 873.

${ }^{23} \mathrm{KHZ}$ 1852, Nr 238, Beilage, s. 1138.

$24 \mathrm{KHZ}$ 1883, Nr 143, Beilage, s. 1976.

$25 \mathrm{KHZ}$ 1894, Nr 43, Zweite Morgensausgabe, s. 699.

${ }^{26} \mathrm{KHZ}$ 1894, Nr 63, Erste Morgensausgabe, s. 1056.

$27 \mathrm{KHZ}$ 1852, Nr 246, s. 1176. 
miała być kojarzona z postawą liberalną. Mimo tego uczniowie państwowego bądź co bądź gimnazjum prezentowali utwory poety na jednym z wieczorów, zorganizowanych przez towarzystwo ${ }^{28}$.

Z pewnością można stwierdzić, że prasa codzienna pogłębia i precyzuje wiadomości na temat pozaszkolnej działalności nauczycieli szkół średnich. Zamieszczane w rocznych sprawozdaniach szkół dane biograficzne na temat nauczycieli, podawane najczęściej w chwili zatrudnienia lub śmierci pedagoga, odnosiły się tylko i wyłącznie do ich kariery zawodowej oraz wykształcenia. W prasie codziennej można natomiast odnaleźć informacje na temat działalności pedagogów na innych płaszczyznach życia publicznego, m.in. dane o ich działalności politycznej. Na łamach $\mathrm{KHZ}$ odnotowywano przede wszystkim informacje o nauczycielach-politykach z partii postępowej (Fortschrittspartei), której - jak zaznaczyliśmy powyżej - gazeta sprzyjała. Odnotowano śmierć wieloletniego nauczyciela gimnazjum kętrzyńskiego Karla Gustava Rahtsa, który był również przez wiele lat przewodniczącym miejskich radnych $w$ Kętrzynie, a w latach siedemdziesiątych XIX w. reprezentował partię postępową w izbie poselskiej ${ }^{29}$. Z informacji zawartych w gazecie wynika, że na początku lat sześćdziesiątych deputowanym z powiatów Ełk, Pisz i Olecko z ramienia partii postępowej był wieloletni nauczyciel gimnazjum w Ełku Wilhelm Orlando Gortzitza ${ }^{30}$. Wiadomości bezpośrednio związane z życiem szkoły i karierą nauczycieli dotyczyły np. wyboru nowego dyrektora danej placówki. W KHZ odnotowano chociażby, że w 1855 r. królewiecka wyższa szkoła obywatelska na Lipniku (dzielnicy Królewca) wybrała na stanowisko dyrektora Alexandra Schmidta, pracującego dotychczas w jednej z gdańskich szkół’¹.

$\mathrm{Na}$ łamach prasy codziennej można również odnaleźć informacje na temat periodycznych konferencji dyrektorów szkół średnich z terenu Prus Wschodnich i Prus Zachodnich. Informowano o czasie, miejscu i tematyce tych cyklicznych spotkań reprezentantów szkół realnych i gimnazjów. Historyk edukacji dowiaduje się na ich podstawie, jakie problemy były najbardziej istotne dla osób kierujących szkołami średnimi w prowincjach pruskich, jakimi zagadnieniami dotyczącymi programu i metod zajmowano się. $Z$ relacji pokonferencyjnych można się także dowiedzieć, że wielu nauczycieli ze wschodniopruskich szkół średnich aktywnie uczestniczyło w obradach ${ }^{32}$.

Niekiedy informacje publikowane w rubryce „Provinzielles” podawano za sprawozdaniem rocznym danej szkoły średniej. Tym wzmiankom towarzyszyły często uwagi recenzyjne anonimowego autora relacji na temat szkolnego wydawnictwa. Na przykład sprawozdawca z Kłajpedy donosił o zawartości programu tamtejszej wyższej szkoły obywatelskiej, zwracając uwagę przede wszystkim

\footnotetext{
${ }^{28} \mathrm{KHZ}$ 1862, Nr 26, Beilage.

$29 \mathrm{KHZ}$ 1883, Nr 132, Abendausgabe, s. 1823.

$30 \mathrm{KHZ}$ 1862, Nr 68, Beilage, npg.

$31 \mathrm{KHZ}$ 1855, Nr 39, s. 188.

32 Zob. np. KHZ 1883, Nr 148, Beilage, s. 2045; Nr 177, Beilage, s. 2408.
} 
na radzenie sobie z nieszczęściem, jakim była utrata budynku w 1854 r. i pomoc, jakiej udzieliły szkole lokalna społeczność oraz władze zwierzchnie. Autor relacji oceniał ponadto w samych superlatywach rozprawę naukową, dołączoną do sprawozdania, i podkreślał, że na tle innych tego typu publikacji wypada bardzo korzystnie ${ }^{33}$.

Zamieszczano również wzmianki o wizytach prominentnych gości w szkołach i na bieżąco przedstawiano wrażenia z tego typu spotkań. Na przykład w Olsztynku na początku 1855 r. rewizji progimnazjum dokonał tajny radca ministerium oświaty Ludwig Wiese. Jego wizytę odbierano jako wyraz aprobaty ze strony władz zwierzchnich dla dotychczasowej działalności szkoły i wiązano z nią nadzieję na przekształcenie olsztyneckiego progimnazjum w pełną szkołę średnią (czyli gimnazjum) ${ }^{34}$. W rubryce „Provinzielles” informowano ponadto o staraniach poszczególnych szkół, zmierzających do poprawy warunków lokalowych. Na przykład w Welawie z powodu remontu budynku szkolnego w 1855 r. wydłużono czas trwania wakacji letnich ${ }^{35}$. Na łamach $\mathrm{KHZ}$ donoszono także o przebiegu egzaminów maturalnych w poszczególnych szkołach ${ }^{36}$. W krótkich informacjach podawano zazwyczaj termin egzaminu, liczbę uczniów, którzy do niego przystąpili oraz dane liczbowe o wynikach ${ }^{37}$.

Dokonując analizy zawartości prasy codziennej jako źródła do historii edukacji, należy zwrócić uwagę na ogłoszenia drobne, których znaczenie jako materiału źródłowego podkreślono już w literaturze ${ }^{38}$. Szkoły średnie zamieszczały je głównie w okresie rozpoczęcia nowego roku szkolnego lub semestru. W KHZ zamieszczali swe oferty nie tylko nauczyciele szkół królewieckich, lecz także dyrektor gimnazjum z Olsztyna. W ogłoszeniach podawano informacje o terminach rozpoczęcia roku szkolnego i naboru nowych uczniów oraz wymaganych dokumentach, które kandydaci mieli przedłożyć władzom szkolnym ${ }^{39}$. W pierwszej połowie stulecia, kiedy zarówno dział informacji z prowincji, jak i ogłoszeń drobnych miały mniej usystematyzowany charakter, na łamach gazety pojawiły się również ogłoszenia i anonse istotne dla historyka edukacji. W przypadku nauczycielskiej działalności gospodarczej można przywołać przykład pedagoga z gimnazjum ełckiego, Wilhelma Menzla, który obok pracy w szkole trudnił się również prowadzeniem zakładu typograficznego w Ełku i oferował na łamach królewieckiej gazety sprzedaż pomocy dydaktycznych - globusów ${ }^{40}$.

W konkluzji należy więc stwierdzić, że dzięki analizie zawartości KHZ historyk edukacji może odnaleźć wiele szczegółowych informacji na temat męskiego

$33 \mathrm{KHZ} 1855, \mathrm{Nr} 260$, s. 1386.

34 Tamże, Nr 162, Beilage, s. 864.

$35 \mathrm{KHZ}$ 1883, Nr 148, Beilage, s. 2044.

36 Zob. np. o gimnazjum olsztyńskim - KHZ 1888, Nr 201, Beilage, Abendblatt, s. 3020.

37 Por.: KHZ 1897, Nr 19, Erste Morgenausgabe, s. 304.

38 B. Krzy w o bło c k a, Prasa..., s. 68.

$39 \mathrm{KHZ}$ 1897, Nr 230, Erste Morgenausgabe, s. 4012.

40 „Königlich Preußische Staats-, Kriegs- und Friedens Zeitung“ 1839, Nr 5, s. 37; G. J a s i ń s k i, Wstęp, „Przyjaciel Ludu Łecki (ełcki)“, Roczniki 1842 i 1844 wraz z „Przydatkiem“, Ostróda 2010, s. 24. 
szkolnictwa średniego w Prusach Wschodnich w XIX w. Problematyka edukacyjna oczywiście nie dominowała na łamach gazety, pojawiała się jednak regularnie w doniesieniach z prowincji, a niekiedy stanowiła temat głównego artykułu lub felietonu, w których poruszano problemy tego szczebla oświaty z perspektywy nieznanej z innych źródeł. KHZ jest przykładem prasy codziennej informacyjnej, na podstawie której historyk edukacji może pogłębić informacje o dyskusji toczonej w państwie pruskim na temat kształtu szkolnictwa średniego, a także zweryfikować dane uzyskane w wyniku kwerendy innych źródeł, dotyczące m.in. rozwoju poszczególnych placówek, remontu budynków, ważnych szkolnych wydarzeń. Zamieszczane w prasie codziennej informacje pozwalają więc bliżej poznać rozwój pruskiej myśli pedagogicznej i działalność instytucji publicznych, jakimi były szkoły. 